\title{
Feasibility Study for a \\ Utility-Scale Wind Project
}

\section{DE-FG36-05G015179}

Ken Lomayestewa, Director

$7 / 30 / 2010$

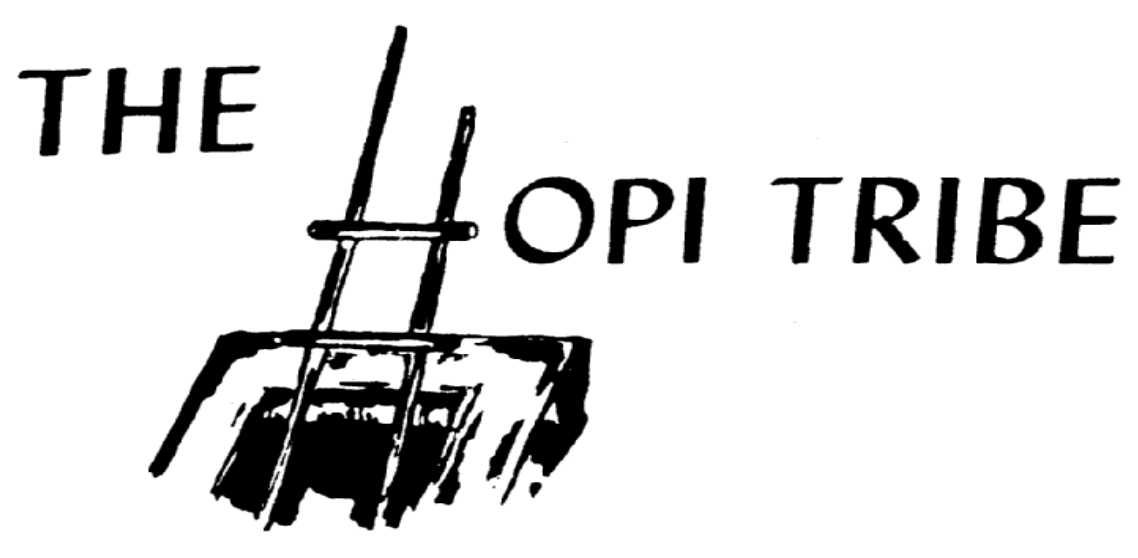

The Hopi Tribe will conduct a feasibility study to determine if development of a utility-scale wind power project with a capacity of approximately $100 \mathrm{MW}$ located on Hopi land held in fee simple in northeastern Arizona is feasible. 
THE 1 OPI TRIBE

Award Number:

Recipient Organization: The Hopi Tribe

Project Title:

Partners:

Technical Contact:

\section{$\underline{\text { Final Report }}$}

\section{DE-FG36-05GO15179}

Feasibility Study for a Hopi Utility-Scale Wind Project

The Hopi Tribe and the U.S. Department of Energy

Kendrick Lomayestewa, Director

Hopi Renewable Energy Office

P.O. Box 123

Kykotsmovi, Arizona 86039

Telephone Number: 928-734-7147

Fax Number: 928-734-7148

klomay@hopi.nsn.us

Business Contact: Joseph Begay, Director

Financial Management

P.O. Box 123

Kykotsmovi, Arizona 86039

Telephone Number: 928-734-3317

Fax Number: 928-734-3317 


\section{Table of Contents}

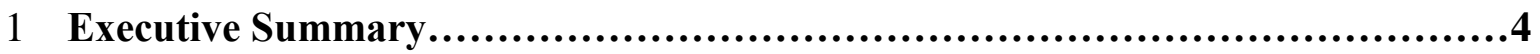

2 Hopi Energy and Environmental Context.........................................4

2.1 Hopi Energy Planning Activities.......................................5

2.2 Project Overview..........................................................6

2.3 Project Site and Land Issues.............................................6

$2.4 \quad$ Transmission and Integration...........................................6

2.5 Environmental Benefits and Potential Impacts...............................7

2.6 Economic Development................................................

2.7 Available Renewable Resources..........................................8

$2.8 \quad$ Level of Hopi Commitment................................................9

2.10 Closing Comments........................................................ 


\section{Executive Summary:}

This is the final report for the Utility-Scale Wind Feasibility Study project conducted to determine if the Hopi Lands have a viable wind resource for commercial generation and to investigate the viability and implementation of a Tribal Utility Authority capable of conducting energy business on the reservation.

Due to certain unforeseen threats and downfalls to the economy of the Hopi Tribe, other alternative sources of revenue based projects are being investigated. According to the NREL's Wind Resource Maps, the Hopi reservation and fee simple lands located in northeastern Arizona have potential for wind power development. A number of commercial wind and solar developers had proposed developments to the tribe. A limited number of wind data collection equipment have been installed in the surrounding boundaries of the proposed Hopi wind study sites but none have been installed directly on the proposed study areas. Northern Arizona University has a 30m Met Tower near the boundary of the Hopi study site. The University uses data from this tower for educational purposes which is one source for wind data but as technology advances and heights of meteorological towers increase, qualitative data collection becomes an issue for a credible and bankable project therefore, newer and taller towers are proposed.

The goal of this project was to investigate the feasibility for the generation of energy from wind and to parallel this work with the development of a tribal utility organization capable of undertaking potential joint ventures in utility businesses and projects on the Hopi reservation.

Wind resource assessments were conducted at two study sites on Hopi fee simple lands located south of the city of Winslow. Reports from the study were recently completed and have not been compared to any existing historical wind data nor have they been processed under any wind assessment models to determine the output performance and the project economics of turbines at the wind study sites. Ongoing analysis of the wind data and project modeling will determine the feasibility of a tribal utility-scale wind energy generation.

\section{Hopi Energy and Environmental Context}

The Hopi Tribe has continuously occupied the Coconino Plateau since 500 AD, thriving in the relatively harsh environment by living in balance with nature. However, over the last 150 years, over $90 \%$ of the traditional Hopi Lands have been lost and the Hopi people have come to experience chronic economic difficulty. According to US census figures, the median Hopi household income is only one half that for the median non-Indian Arizona household. Official unemployment rates on the reservation are over 30\%, about six times higher than the rate for the state of Arizona and Hopi unemployment estimates on the reservation are even greater.

In the mid 1960's, the Hopi and Navajo Tribes at the urging of the US federal government and various energy companies, signed coal leases on Black Mesa establishing the largest surface coal mining operation in the nation. Coal mined on the reservation fuels the 1,580 megawatt (MW) Mohave Generating Station in Laughlin, Nevada. The coal was transported via the only long distance slurry line in the US which draws water from the N-Aquifer on the Hopi and Navajo reservation. Faced with an absence of other economic opportunities, the Hopi Tribe has grown dependent on coal mining royalty payments. These revenues, approximately $\$ 7.5$ million per year, make up $80 \%$ of the Hopi Tribe's annual budget and pay for essential governmental services and programs including health care, education and law enforcement. 
Unfortunately, the coal mining and slurry operation are not environmentally sustainable. The coal slurry operation is pumping water from the $\mathrm{N}$-Aquifer faster than the aquifer recharges and this aquifer is the sole source of drinking water for the growing population of the Hopi, Navajo and Paiute Tribes. Despite the potentially devastating economic impacts of halting the coal mining and slurry operation, the Hopi Tribe have opposed continued coal mining at Black Mesa until a method can be identified to transport the coal without depleting the N-Aquifer. The Hopi, Navajo and Paiute Tribes are working with Peabody Energy and Department of Interior on a number of approaches to solve this problem. However, without an agreed solution the Mohave plant has shutdown at the end of 2005.

\subsection{Hopi Energy Planning Activities}

In 1995, the Hopi Tribe established the "Hopit Potskwaniat", a comprehensive strategic plan to provide a framework for Tribal decision making. This plan was updated in 2001 and since then, with the concerns about the shutdown of the Mohave plant, the Hopi Tribe have undertaken a multi-year economic development planning effort and assessment of environmental and economic impacts of various energy options. Funding was sought and received from a number of federal funding sources to undertake these activities.

Funding from Administration for Native Americans (ANA) was used to investigate the merits of the Hopi Tribe acquiring and operating their own distribution assets and potentially establishing a Hopi Tribal Utility Authority. Funds from the Environmental Protection Agency (EPA) for the Hopi Clean Air Partnership Project were used to identify strategies to improve air quality on the reservation and ways to diversify away from its coal-dominated economy to one that integrates sustainable technologies and attract clean businesses.

The Hopi Tribe received support from DOE's First Step towards Developing Renewable Energy and Energy Efficiency on Tribal Lands program. Building on the EPA Partnership project, funds from this grant were used to carry out a broad based energy needs assessment and energy options analysis, exploring both energy efficiency and distributed generation opportunities on the reservation. This work also explored renewable energy and other business opportunities with a focus on exporting energy off the reservation. As a result of these efforts, the Hopi Tribe has developed a Hopi Sustainable Energy Program that will provide input to the Tribe's governing bodies and planned Hopi Tribal Utility Authority to foster businesses that provide energy systems or services based on sustainable energy technologies. The Hopi Tribe received a six month extension to the First Steps grant and presented the draft Hopi Sustainable Energy Plan at a Hopi Energy Fair that was held on March 22, 2005 at the Hopi Junior Senior High School in Polacca, Arizona. After this event, the Sustainable Energy Plan was presented to the Hopi Tribal Council and final reports for the First Steps grant submitted to DOE.

Successfully developing the Sunset Mountain wind project would be a major step towards alleviating Hopi social economic environmental and cultural problems. Revenues from the project will directly offset the loss of revenues from lost coal sales, potentially to a large degree if the Hopi Tribe maintains a substantial equity stake in the project. These revenues will work to support critical Hopi social programs that may otherwise face serious funding shortfalls. Jobs and internships related to the wind project would help alleviate chronic unemployment and provide a high-tech new career development avenue for Hopi youth that is consistent with Hopi traditional values. The movement of Hopi youth away from both the reservation and traditional values poses a severe threat to the survival of Hopi culture. Finally, the 
generation of electricity without long-term damage to the land, water consumption, or harmful emissions would help put the Hopi economy and environment on a truly sustainable path.

\subsection{Project Overview}

The Hopi plan was to complete a feasibility study to develop a utility-scale wind project with a capacity of $100 \mathrm{MW}$ in northeastern Arizona. The consultant who was to work with the Tribe selected the area on two large mesas called East and West Sunset Mountain approximately 16 miles south of the city of Winslow, Arizona. The project site is located in Coconino County. The proposed project elements are listed:

- Land - There is approximately 2,680 acres of Hopi Lands held in fee simple and have now been turned into Trust status for Hopi.

- Wind Resource - The Consultant expected Class 3 or 4 based on information from 2 years of nearby anemometer data, which was evaluated by a meteorologist, and the Arizona state wind map produced in collaboration with the DOE National Renewable Energy Laboratory (NREL).

- Interconnect - The Consultant was to work with Arizona Public Service (APS) for the $69 \mathrm{kV}$ transmission line two miles from the proposed site.

- Power Purchaser - APS, to serve increasing state Environmental Portfolio Standard renewable energy requirements.

\subsection{Project Site and Land Issues}

The first site selected by the consultant was on top of the Sunset West Mountain, a 50m MET tower was constructed and one year of wind data was collected. Traditional Clan leaders who use this area for eagle gathering were not informed or included in the project, due to cultural sensitivity issues of the site selected, the consultant was ordered to dismantle and remove the tower. The current alternate sites are now located in the flats north of the Sunset East mountain.

The lower Sunset Mountain flats area is large enough to accommodate approximately $100 \mathrm{MW}$ of installed wind capacity. Interconnect costs will be low, given relatively low voltage 69 kilovolt transmission line and proximity of the line within two miles of the project site. Existing dirt roads that provide access to the site should be suitable for construction activities with minor improvements.

The tribe will continue to work with the Arizona State Lands Department for any Rights of Ways issues to construct a lateral tie line from the project to the APS $69 \mathrm{kV}$ transmission line.

\subsection{Transmission and Integration}

With information from APS and the past Consultant, the Sunset Mountain project is looking at interconnecting into the 69 kilovolt line which runs along State Route 87 from Winslow to growing loads in the area of Blue Ridge. This APS line conductor is 795 ACSR 9aluminum conductor steel reinforced) capable of carrying 108 MegaVar (MVAr) or approximately $101 \mathrm{MW}$ of power. This line will provide available transmission capacity (ATC) to absorb approximately $671.5 \mathrm{MW}$ turbines (total project capacity 100.5 MW), or potentially somewhat more given growing load at Blue Ridge. This transmission 
line is within two miles of the project site which would be ideal for a relatively low cost electrical project interconnection if the Tribe's Council were to give approval for the project.

One of the factors with this project is that there are also several independent private wind projects being considered east of the Hopi wind study area on State, BLM, and private lands. The Dry Lakes Wind Farm is the only operating project at this time and is located approximately 30 miles from the Hopi sites.

\subsection{Environmental Benefits and Potential Impacts}

Wind is an environmental benign power generation source. Wind power emits no air pollution and utilizes no water, a critical issue in the desert southwest, which suffered through approximately ten years of extreme drought. Preservation of water resources is an especially important issue to the Hopi whose ground water was being depleted by Peabody Coal Company until the slurry operation to the Mohave Generating plant shutdown in 2007.

Operation of the Sunset Mountain project would help reduce the air pollution in the region and would benefit the Hopi and non-Hopis in the region alike. The effects of the Sunset Mountain project displacing gas and coal generation will be the equivalent in terms of carbon dioxide reductions as planting almost 100 acres of forest or removing 36,000 cars from Arizona road ways. In terms of water, the wind project will displace the need to use up approximately 143 million gallons of water per year which would otherwise be used in steam cycle oil, natural gas and coal plants.

The prior Consultant stated the site biological impacts were expected to be relatively low compared to other modern wind projects because the arid area is known to consist of relatively low biological diversity and species intensity. This information was based on the biological assessment done for a nearby Sunshine wind project with which the prior consultant was also involved in with the Hopi Tribe where they stated there was no presence of threatened or endangered species. Habitat conditions at the Sunset Mountain site are expected to be somewhat different due to a significant change in elevation, but still of less biological intensity than at many wind projects located in more fertile areas of the West.

One known concern is the population of Golden Eagles in the area. Whereas Golden Eagles are not on the threatened or endangered species list, the Sunset Mountains area is used in traditional Hopi "eagle gathering" ceremonies. Accordingly, understanding potential impacts to the area, eagle population is a sensitive and cultural concern. Impacts are expected to be low, as substantial Golden Eagle populations and nesting sites have been documented in close proximity to other modern wind farms with only one fatality recorded over three years of operation. With this feasibility study the Hopi Tribe has conducted an Avian Collision study for the two 50 meter MET towers which are installed to collect wind data.

\subsection{Economic Development}

The Hopi Tribe has extreme economic hardship conditions. The Sunset Mountain project site is an hour's drive south of Kykotsmovi and the traditional Hopi village population centers. The development of the Sunset Mountain Project would result in a range of economic stimulus on the Hopi reservation and the surrounding communities.

With a total capital cost for a $100 \mathrm{MW}$ project at approximately $\$ 120$ million, DOE's Job and Economic Development Impact (JEDI) model suggest that local impact on economic output related to building the 
wind project would be approximately $\$ 26$ million during the construction period, approximately $\$ 2$ million annually during the operation phase. Over a six month construction period, approximately 240 local jobs would be created. In the long-term, approximately 18 operations, maintenance security and administrative jobs would be created and an additional 11 jobs would be induced in the local area. These jobs would be targeted for Hopi members whenever practicable.

\subsection{Project Identified Objectives}

The feasibility study was completed by the Hopi Renewable Energy Office with the primary objective of completing this feasibility study for the wind project which was started in 2005. Due to the constant changes with the tribal staffing and issues with the former Consultant not completing the permitting and installation of MET towers, the HREO staff made changes to ensure completion of the project. The objectives were:

- To complete the permitting process with Coconino County for the installation on two 50-meter MET towers.

- To find a consultant to install the MET towers and to train the HREO staff in the process.

- Compile all information relating to the project that had already been completed, and review all files relating to the project.

- Review all reports, documents and information to determine what the issues were and why the project had stalled.

- Conduct professional development and capacity building efforts.

- Conduct public awareness outreach to all Hopi communities on the project and program objectives.

The prior project team identified and listed eleven (11) primary activities however; they did not meet the objectives they identified.

The DOE Tribal Energy Program seeks to promote tribal energy self-sufficiency and to foster employment and economic development on Tribal Lands. While the idea of power from the Sunset Mountain project is to be sold off reservation to APS, the experience and skills that the Hopi will develop in partnering with an experienced energy developer will be useful in promoting self sufficiency and more energy related activities on the reservation. If the development of the project is accepted by Hopi it would stimulate employment of Hopi people and will have a strong economic development effect for the tribe. Adding wind farming to ranching operations on the project site will result in much higher land revenues, construction of the facility will stimulate jobs in the area, and possible revenues in property taxes when the land is in trust status.

\subsection{Available Renewable Resources}

At the beginning of 2008, and without an actual resource data for the site, the Sunset Mountain area was expected to range from a class 2 to a class 4 wind resource. The prior Consultant had consulted Rich Simons, Meteorologist, of Windots, L.L.C. to prepare a wind resource assessment of the site which indicated that there is adequate area to erect a minimum of $100 \mathrm{MW}$ of installed wind capacity in class 3 and class 4 resource areas. This report has not been found and was not turned over to the Tribe. 


\subsection{Level of Hopi Commitment}

In the beginning of the feasibility study the commitment from Hopi was high, but with the changes in the administration of elected officials and tribal Council members and program staff, the intent has somewhat been unsure due to no directives to the new project staff. One of the issues is that the Consultant was the project manager and information is missing on their accomplishments. Hopi project team members are no longer working for the tribe and those remaining have not provided any input.

In late fall of 2008, two of the current project staff the Utility specialist and the Project Manager were hired and were key in continuing the effort to complete the feasibility study. The Hopi Tribe has met the commitment of cost share level of $\$ 20,900$ (7\% of total project costs) through contribution on in-kind service specifically through the two staff, Energy Team members and the Hopi General Counsel's time to the project.

\subsection{Closing Comments}

Since the inception of the formerly titled Hopi Clean Air Partnership Project (HCAPP) in 2005 constant changes in staffing occurred preventing progress in project activities. The current program staff were hired in August and October of 2007. The program title was changed to the Hopi Renewable Energy Office (HREO) in 2010 to better coincide with project objectives. The previously retained Energy Consulting Company was also released due to non-activity in the progress of project development. Therefore the following information in this report is limited to project activities starting from dates the current staff were retained, due to remaining funding and timelines for the grant, changes were made to the original award project outline to prioritize and accomplish those activities listed in 2.7 of this document.

The Hopi Tribe is investigating the opportunities for renewable energy projects other than the Sunset Mountain Wind project. The completed Wind Assessment Report was presented to Council on April 25, 2011, the report will also be provided to the Hopi Public for their input and involvement in the planning phase. No response or directive has been announced to the HREO from the Council on whether to proceed with development. If the Tribe and Hopi public support the Wind Assessment Report and feasibility deliverables, and determine the project sites on Hopi have a viable wind resource, it may gain favorable support to continue moving forward. The Tribe will then request for additional funding through DOE or other funding sources to plan in development of the proposed 100MW Hopi Wind Farm. 